\title{
High pressure and thermal processing on the quality of zucchini slices
}

\author{
Maria Paciulli ${ }^{1}$ (1) - Tommaso Ganino ${ }^{1,2}$ - Ilce Gabriela Medina Meza ${ }^{3} \cdot$ Massimiliano Rinaldi $^{1} \cdot$ Margherita Rodolfi $^{1}$. \\ Michele Morbarigazzi $^{4} \cdot$ Emma Chiavaro $^{1}$
}

Received: 2 September 2020 / Revised: 22 October 2020 / Accepted: 24 October 2020 / Published online: 9 November 2020

(C) The Author(s) 2020

\begin{abstract}
In response to the market demand for low processed vegetables, high-pressure treatments $(400,600 \mathrm{MPa} ; 1,5 \mathrm{~min})$ were applied on zucchini slices and compared to a traditional blanching treatment. Histological observations, texture and color analysis, pectinmethylesterase (PME) and antioxidant (DPPH) activities were measured and compared to untreated samples. The histological observations revealed that the longer high-pressure treatments $(5 \mathrm{~min})$ led to more extended cell lysis and dehydration than the shorter ones $(1 \mathrm{~min})$ and blanching. High-pressure treatments resulted less effective than blanching on PME inactivation, with the best results obtained at $400 \mathrm{MPa}$ for $1 \mathrm{~min}$. Comparable texture parameters were observed for high-pressured and blanched samples. The negative correlation found between PME activity and the texture parameter 'distance of the first peak force' revealed an effect of PME on the texture recovery after treatments. High pressure led to a general browning of zucchini parenchyma and to DPPH drop. The correlations found between DPPH and color suggest the common nature of the phenomena. The influence of pressure and time on the studied parameters was revealed by two-way ANOVA. Principal component analysis clustered together the four high-pressure-treated samples, being clearly divided by blanched and untreated ones.
\end{abstract}

Keywords High pressure $\cdot$ Vegetables $\cdot$ Structure $\cdot$ Enzymatic activity $\cdot$ Antioxidant activity

\begin{tabular}{ll}
\multicolumn{2}{l}{ Abbreviations } \\
$a^{*}$ & Greenness \\
ANOVA & Analysis of variance \\
2 W-ANOVA & Two-way ANOVA \\
$b^{*}$ & Yellowness \\
BL & Blanching \\
C & Chroma \\
DistanceP1 & Distance of the first peak force $(\mathrm{mm})$ \\
DPPH & 2,2-Diphenyl-1-picrylhydrazyl \\
F\&V & Fruits and vegetables
\end{tabular}

Maria Paciulli

maria.paciulli@unipr.it

$\bowtie$ Ilce Gabriela Medina Meza

ilce@msu.edu

1 Department of Food and Drug, University of Parma, Parco Area delle Scienze 27/A, 43124 Parma, Italy

2 Institute of BioEconomy (IBE), National Council of Research - CNR, Sesto Fiorentino, FI, Italy

3 Department of Biosystems and Agricultural Engineering, Michigan State University, 469 Wilson Road, East Lansing, MI 48824, USA

4 HPP Italia, Traversetolo, PR, Italy

$\begin{array}{ll}\text { Fp1 } & \text { First peak force (N) } \\ \text { Fmax } & \text { Maximum puncture force (N) } \\ h^{\circ} & \text { Hue angle } \\ \text { HP } & \text { High pressure } \\ \text { HPP } & \text { High-pressure processing } \\ \text { L } & \text { Lightness } \\ \text { PCA } & \text { Principal component analysis } \\ \text { PG } & \text { Polygalacturonase } \\ \text { PME } & \text { Pectinmethylesterase } \\ \text { POD } & \text { Peroxidase } \\ \text { PPO } & \text { Polyphenoloxidase } \\ \text { PVPP } & \text { Polyvinylpolypyrrolidone } \\ \text { TE } & \text { Trolox equivalents } \\ \text { TBO } & \text { Toluidine blue }\end{array}$

\section{Introduction}

Fruit and vegetables ( $F \& V)$ consumption is mainly linked with a healthy diet [1]. Consumers, therefore, aim to purchase organoleptically inviting F\&V with an adequate nutritional content [2]. Fresh F\&V often meet this type of expectation, on the other hand, they have short shelf lives 
and unpractical use, which do not fit well with the current lifestyles.

To meet the current market needs, novel non-thermal technologies are being studied [3, 4] with the aim to stabilize the products avoiding the detrimental effect of temperature [5]. In this context, high-pressure processing (HPP), applying pressure in the range between 100 and $1000 \mathrm{MPa}$ for small periods of time, can deactivate pathogens and spoiling microorganisms, avoiding the detrimental effect of temperature [6].

In the field of F\&V, HPP has mainly being applied on juices [7], beverages [8], purée [9] or sauces [10]. The effect of this technology on the quality of whole or pre-cut F\&V is less debated.

Paciulli et al. [11], observed that high-pressure treatments at 200, 400 and $600 \mathrm{MPa}$ for $5 \mathrm{~min}$ softened pumpkin cubes less than a thermal treatment at $85^{\circ} \mathrm{C}$ for 5 min. Modifications of cell morphology, membrane integrity and pectin properties were considered responsible for this change. During the two months of storage, the same authors observed further texture loss for the HP-treated pumpkins, associated to residual pectinmethylesterase (PME) activity. The barotolerance of some $\mathrm{F} \& \mathrm{~V}$ spoiling enzymes has been reported by many authors [12]. The main enzymes related to $F \& V$ consistency are polygalacturonase (PG) and PME, their synergistic activity leads to tissue softening during ripening. While PG appears to be one of the most pressure-labile enzymes, PME showed high-pressure resistance. Shook et al. [13] found no PG activity in tomato dices treated at $800 \mathrm{MPa}$ for one minute, on the contrary, no inactivation of PME was observed in the same conditions. Polyphenol oxidase (PPO) and peroxidase (POD) are the two main enzymes responsible for color change in $\mathrm{F} \& \mathrm{~V}$, leading also to loss of some bioactive compounds [12]. Many of the PPOs investigated are extremely resistant to high-pressure inactivation, while PODs resistance varies depending on the source [12]. The relation between enzymatic activity and color has been highlighted by many authors, especially during storage [14]. However, as covalent bonds are not affected by pressure, HPP was found to be less detrimental than thermal processes to low-molecular-weight molecules like pigments. Krebbers et al. [15] showed that the green color of green beans becomes even more intense (decrease in $L^{*}, a^{*}$ and $b^{*}$ values) after HPP at $500 \mathrm{MPa}$ for $1 \mathrm{~min}$, however, at elevated temperature, the color shifted visibly to olive green. Paciulli et al. [16] showed that blanching affected blueberries color more than HPP at 400 and $600 \mathrm{MPa}$ for 1 and $5 \mathrm{~min}$. HPP may yield to more intense colors or bioactive activities, because of the leakage of small molecules, such as pigments or health-related compounds, from the broken cells. Castro et al. [17] applying HP to green and red peppers observed a better retention of ascorbic acid than on blanched samples, particularly for red peppers, that showed even an increase. Similarly, Paciulli et al. [18], found a better extraction of betanins, phenols and ascorbic acid from beetroots slices treated at $650 \mathrm{MPa}$ from 3 to $30 \mathrm{~min}$ in comparison to blanched ones. On the other hand, McInerney et al. [19] did not find any difference in carotenoid content among untreated and HP-treated (400 and $600 \mathrm{MPa} / 2 \mathrm{~min}$ ) carrots, green beans and broccoli.

To the best of our knowledge, the application of HPP on zucchini slices has been tested only once [20]. Due to the significant softening and quality degradation of the thermal treated controls, no comparison was possible, thus no deeper investigations were conducted.

This study aims to investigate the effect of HP treatments at 400 and $600 \mathrm{MPa}$ for 1 and $5 \mathrm{~min}$ on the quality parameters of zucchini slides.

\section{Materials and methods}

\section{Sample preparation}

Zucchini (Cucurbita pepo L, cv. Nero di Milano) was purchased from a local market in Parma, Italy. Zucchini with a diameter of $30 \pm 0.1 \mathrm{~mm}$ was washed and drained, the upper and the lower parts were removed, and the samples were cut, using a slicer, into slices of $8 \mathrm{~mm}$ thickness.

\section{Treatments}

Untreated zucchini (R) was subjected to five different treatments, as described:

\section{Blanching (BL)}

In accordance with Paciulli et al. [21], zucchini slices were immersed in a water bath (sample/water ratio of 1:5) at $90 \pm 2{ }^{\circ} \mathrm{C}$ for $2 \mathrm{~min}$. The treatment was conducted in triplicate.

\section{High-pressure (HP) treatments}

HP treatments at 400 and $600 \mathrm{MPa}$, both for 1 and $5 \mathrm{~min}$ (HHP400-1; HHP400-5; HHP600-1; HHP600-5) were carried out using a $300 \mathrm{~L}$ high-pressure plant (Avure Technologies Inc.), at "HPP Italia" of Traversetolo (Italy), using cold water $\left(4{ }^{\circ} \mathrm{C}\right)$ as pressure medium. All the HP treatments were conducted at room temperature $\left(\sim 20^{\circ} \mathrm{C}\right)$, considering a temperature increase due to compression, not higher than $2-3{ }^{\circ} \mathrm{C} / 100 \mathrm{MPa}$. For the HP treatments, zucchini slices were vacuum-sealed in flexible (75 mm thickness) plastic pouches (Ultravac Solutions, Kansas City, MO, USA). Three pouches were processed and analyzed for each treatment condition. 


\section{Moisture content}

Five $\mathrm{g}$ of untreated and treated ground samples was dried in a convection oven (ISCO NSV 9035, ISCO, Milan, Italy) at $105{ }^{\circ} \mathrm{C}$ for at least $16 \mathrm{~h}$ until constant weight [22]. The analysis was conducted in triplicate.

\section{Histological analysis}

As reported in detail by Paciulli et al. [16] for blueberries, untreated and treated zucchini slices were first fixed in FAA solution, then dehydrated with increasing alcohol concentrations solutions, thus included in methacrylate resin. The resulting blocks were sectioned in $4 \mu \mathrm{m}$ thickness slices then stained with Toluidine Blue (TBO) or with a FeSO4 solution for the analysis of Tannins [23]. Four pieces of each vegetable and each treatment were analyzed.

Sections were observed with a Leica DM 4000B optical microscope (Leica Imaging Systems Ltd., Wetzlar, Germany) equipped with a Leica DMC 2900 digital camera (Leica Imaging Systems Ltd., Wetzlar, Germany). The measurements were done by the image analysis system LAS v4.10.0 (Leica Application Suite, Wetzlar, Germany) using a manual configuration. At least ten slides carried ten zucchini sections each, for each condition was observed.

\section{Pectin methylesterase (PME) activity}

The test was performed following the method described by Paciulli et al. [16]. The enzyme, extracted with a solution of $1 \mathrm{M} \mathrm{NaCl}$ containing $1 \%$ polyvinylpolypyrrolidone (PVPP), was mixed with $0.5 \%$ pectin, $0.01 \%$ bromothymol blue and water. The progressive discoloration of the blue solution, because of the enzymatic activity, was monitored every $15 \mathrm{~s}$ at $620 \mathrm{~nm}$ for two minutes by a Perkin Elmer UV-Visible spectrophotometer. PME activity was calculated from the slope of the linear segment absorbance-time, measuring the percentage variation of the treated samples in comparison to the untreated one. The analysis was conducted in triplicate.

\section{Texture analysis}

Texture was analyzed using a TA.XT2i Texture Analyzer equipped with a $25 \mathrm{~kg}$ load cell (Stable Micro Systems, Godalming, UK), at a trigger force of $0.01 \mathrm{~N}$. Puncture test was performed using a $2 \mathrm{~mm}$ diameter stainless steel needle probe, driven up in a radial direction to the center of the samples at a speed of $3 \mathrm{~mm} \mathrm{~s}^{-1}$, following the method of Paciulli et al. [21]. First peak force $\left(F_{\mathrm{p} 1}, \mathrm{~N}\right)$ and maximum puncture force $\left(F_{\max }, \mathrm{N}\right)$ were extracted from the force $v s$ time curves. The distance of the first peak force (Distance ${ }_{\mathrm{P} 1}, \mathrm{~mm}$ ), was measured as the space travelled by the needle probe from the contact with the epidermis up to the breaking point. These parameters were quantified using the application software provided (Texture Exponent for Windows, version 6.1 10.0). 10 vegetables were analyzed for each treatment.

\section{DPPH free radical scavenging activity test}

The test was performed according to Paciulli et al. [16]. The antioxidant molecules, extracted in methanol/water (70:30 v/v) solution, were mixed with the DPPH methanolic solution $(0.2 \mathrm{mM})$ and kept in the dark for $30 \mathrm{~min}$. The absorbance was recorded at $517 \mathrm{~nm}$ by a Perkin Elmer UV-Visible spectrophotometer. The radical scavenging activity $(\mu \mathrm{mol}$ Trolox eq./g dw) was calculated by fitting the values of I\% $(\mathrm{I} \%=[(\mathrm{Abs} 0-\mathrm{Abs} 1) / \mathrm{Abs} 0] \times 100$, where $\mathrm{Abs} 0$ was the absorbance of the blank and Abs1 was the absorbance of the sample) in a standard curve absorbance vs concentration of Trolox methanolic solutions. Analyses were performed in triplicate.

\section{Color}

Color of zucchini slices was measured both on skin and parenchyma by means of a Minolta Colorimeter (CM2600d, Minolta Co., Osaka, Japan) equipped with a standard illuminant D65 and $10^{\circ}$ position of the standard observer. The instrument was calibrated before each analysis with white and black standard tiles. $\mathrm{L}^{*}, a^{*}, b^{*}, \mathrm{C}$, and $h^{\circ}$ [24] were quantified on each sample. $\Delta \mathrm{E}$ of the treated zucchini was calculated in comparison to the untreated ones. 10 determinations were performed for each treatment.

\section{Statistical analysis}

SPSS statistical software (Version 25.0, SPSS Inc., Chicago, IL, USA) was used to perform one-way analysis of variance (ANOVA) among all the different treated samples and twoway $(2 \mathrm{~W})$ ANOVA among the HPP treated samples, using pressure and time as independent variables. LSD post hoc test at a 95\% confidence level $(p \leq 0.05)$ was used to further identify differences among treatments. Pearson correlation was performed to evidence relations among the variables $(p<0.05$; $p<0.01)$.

Principal component analysis (PCA) was performed using normalized variables, as reported by Medina-Meza et al. [25]. Only parameters with factor loadings higher than 0.70 were used for this analysis. 


\section{Results and discussion}

\section{Histological analysis}

\section{Untreated zucchini}

In Fig. 1a and b, the microstructure of untreated zucchini is shown. The external parenchyma of Cucurbita pepo L., cv. Nero di Milano is composed by a single layer of epidermis tissue (mean thickness: $21.1 \mu \mathrm{m}$ ) in which, the cells are covered by an abundant cuticle. Hypoderm (the sub-epidermal tissue) is instead composed by isodiametric, thickened cells, with few intercellular spaces.

Figure $1 \mathrm{a}$ and $\mathrm{b}$ show the structure of zucchini mesocarp. External mesocarp resulted composed by cells of different dimensions, from the smaller in subderm $(12.5 \mu \mathrm{m})$, to the larger in central mesocarp $(38 \mu \mathrm{m})$. The external mesocarp showed high degree of cell-to-cell contact throughout the tissue, with scarce intercellular spaces. The cells of the middle mesocarp had tiny walls and were more separated from each other than in the external mesocarp. Inner mesocarp consisted of a parenchyma composed of larger cells (more than $65 \mu \mathrm{m}$ ). Endocarp resulted organized in large irregular cells; those observations were in accord with the study of Paciulli et al. [21], on zucchini.

In untreated samples, the observation of transverse section stained with Tannins Solution, did not show the presence of tannin inclusions.

\section{Blanched zucchini}

After blanching (Fig. 1c and d), the structure showed only slight variations in comparison to untreated; inner parenchyma cells showed weak dehydration (Fig. 1d). In Fig. 1d, it is possible to observe the presence of wide intercellular spaces and cell separation due to the thermal treatment. The same phenomenon was also observed on other vegetables both blanched [21] or differently cooked [26]. Focusing on tannins, as for untreated samples, after staining with Tannins Solution, their presence was not observed.

\section{HPP400-1}

Zucchini slices treated at $400 \mathrm{MPa}$ for one minute did not show significant histological changes, compared to the untreated samples (Fig. 2a). From Fig. 2a, it is possible to observe swelling of cellular walls (in epidermis and subdermis) and a mild dehydration. Dehydration was also observed by Araya and collaborator [27] after HPP treatments at 100, 200 and $300 \mathrm{MPa}$ on carrots, with an initial temperature of $20{ }^{\circ} \mathrm{C}$. The use of Tannins Solution stain on zucchini sections, highlighted the presence of scarce quantities of tannins mainly in the endocarp and near the seeds.

\section{HPP-400-5}

HPP treatment at $400 \mathrm{MPa}$ for $5 \mathrm{~min}$, did not damaged significantly the zucchini microstructure (Fig. 2b). The
Fig. 1 Transverse sections of zucchini samples stained with Toluidine Blue O: a magnification of external tissue (epi- and hypodermis) of untreated/ uncooked samples; b magnification of internal tissue (mesocarp and endocarp) of untreated/ uncooked samples; c magnification of external tissue (epi- and hypodermis) of blanched samples; $\mathbf{d}$ magnification of internal tissue (mesocarp and endocarp) of blanched samples. I $p=$ hypodermis; $\mathrm{s}=$ seed; $\mathrm{d}=$ dehydrated cells; $\mathrm{dc}=$ detached cells
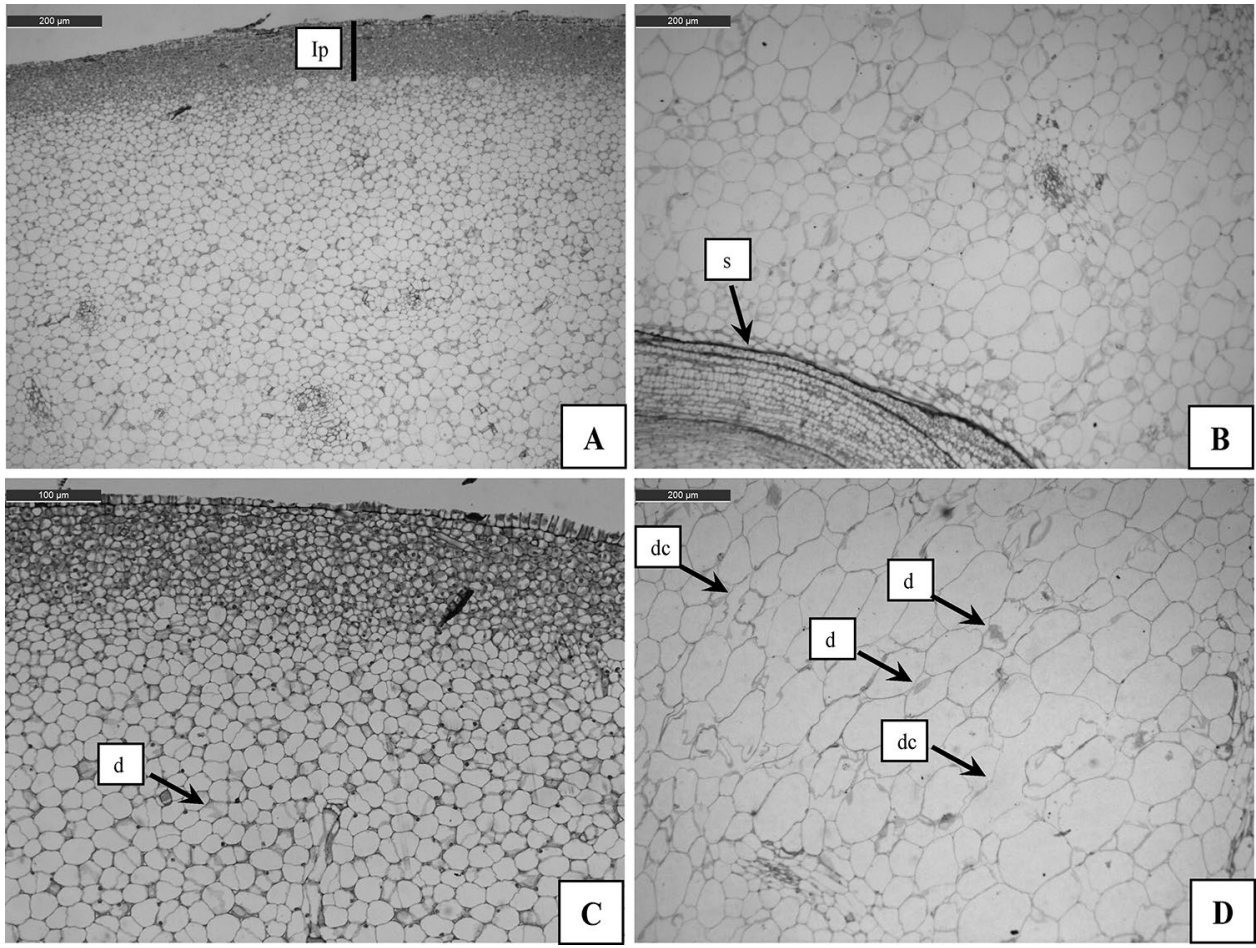
Fig. 2 Transverse sections of zucchini samples stained with Toluidine Blue O: a magnification of external tissue (epi- and hypodermis) of sample treated with $400 \mathrm{MPa}$ for $1 \mathrm{~min}$; b magnification of external tissue (epi- and hypodermis) of sample treated with $400 \mathrm{MPa}$ for 5 min; c magnification of endoderm tissue of sample treated with $400 \mathrm{MPa}$ for $5 \mathrm{~min}$; d magnification of external tissue (epi- and hypodermis) of sample treated with $600 \mathrm{MPa}$ for 5 min. $d=$ dehydrated cells; $\mathrm{sw}=$ Swelling of cell walls; $1=$ lacuna in the tissue due to the HPP treatment
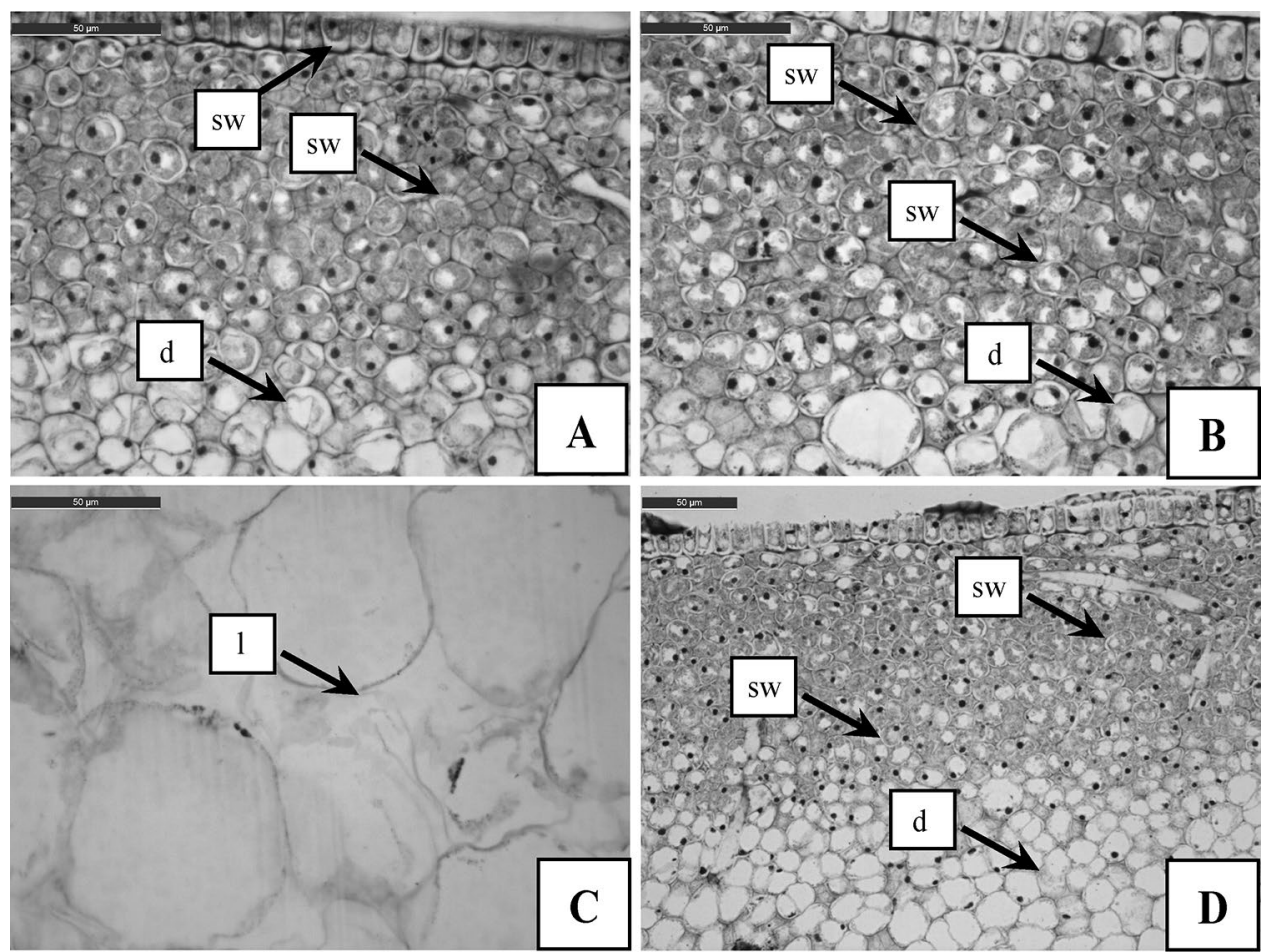

changes were similar to those observed after 1 min treatment (swelling of cellular wall in epidermis and subdermis tissues), even if a more intense dehydration than HPP 400-1 was observed, being also more uniformly distributed in all the tissues. Inner parenchyma showed the major damages in comparison with the other tissues, with evidence of cellular walls lysis (Fig. $2 b$ and c). Tannin Solution stain evidenced the presence of tannins inclusion only near zucchini's seeds, as observed for HPP400-1.

\section{HPP-600-1}

The treatment at $600 \mathrm{MPa}$ for 1 min reflected the same changes observed for HPP400-1, both for the microstructure of tissues and for the presence of tannins.

\section{HPP600-5}

Zucchini treated at $600 \mathrm{MPa}$ for 5 min showed similar effects on microstructure than those observed after the treatment at $400 \mathrm{MPa}$ for $5 \mathrm{~min}$. From the microscopic observations (Fig. 2d), swelling of the cellular walls and cell walls breakage of the inner parenchyma larger cells was observed. Moreover, diffuse dehydration of the tissue was highlighted. The analysis of tannins showed the same trend of HPP400-1.

\section{PME activity}

From Table 1, it is visible how blanching reduced zucchini PME activity to $18 \%$, in comparison to untreated samples. This result confirms the strong effect of thermal treatments on this class of enzymes. High-pressure treatments resulted less effective than blanching on PME inactivation (Table 1). In particular, HPP400-1 and HPP400-5 resulted, respectively, the most and less effective among the studied treatments, leading, respectively, to $27 \%$ and $14 \%$ PME inactivation. Moreover, while longer treatment time at $400 \mathrm{MPa}$ led to lower PME inactivation, at $600 \mathrm{MPa}$ the opposite trend was observed: the longer the exposure time, the higher the enzyme inactivation. Therefore, the $2 \mathrm{~W}$-ANOVA showed a significant interaction between treatment time and applied pressure (Table 1). The high PME baroresistance was already reported in other studies, showing a high speciesspecific behavior. Paciulli et al. [16], treating blueberries at 400 and $600 \mathrm{MPa}$ for 1 and $5 \mathrm{~min}$ observed the same trend of this study, with HHP400-1 as the most effective high-pressure treatment, leading to a PME inactivation of around 35\%. Sila et al. [28], treating shredded carrots with HPP, observed an increase of PME activity up to $400 \mathrm{MPa}$ and a further decrease up to $600 \mathrm{MPa}$. This behavior has been related to reversible configuration of the enzyme and/ or substrate. The PME activity led to the formation of Low Methoxyl Pectin, known to form stable gels under high-pressure treatments [14]. The swollen cell walls, observed by the 
histological analysis on the high-pressure-treated zucchini, may be related with the formation of this gel network.

\section{Texture}

The texture parameters are reported in Table 2. The differences observed between samples cannot be attributable to water loss, since the water content was not affected by the treatments (Table 1). They can be related to tissues modifications and residual enzymatic activity (Paragraphs 3.1 and 3.2).

The first peak force $\left(F_{\mathrm{P} 1}\right)$, related to the resistance opposed by the external cell layers to needle penetration, was not affected by BL in accordance with the histological observations (Fig. 1c and d; Par. 3.1) and with a previous study conducted in the same conditions [21]. Among the HP treatments, HPP400-1 resulted the most influencing one, with $\mathrm{F}_{\mathrm{P} 1}$ drop of around $15 \%$ in comparison to $\mathrm{R}$. The 2 W-ANOVA, conducted among the HP-treated samples, revealed a dependence of $\mathrm{F}_{\mathrm{P} 1}$ from pressure and time, with HPP600-5 showing the highest values $(0.49 \pm 0.03 \mathrm{~N})$.

Distance $_{\mathrm{P} 1}$ underwent a significant increase compared to $R$, for all the studied treatments. An increase of the distance may be described as a general decrease of the tissue crispiness [29]. BL, HPP400-1 and HPP600-5 increased Distance $_{\mathrm{P} 1}$ of around $78 \%$ in comparison to $R$, while for HPP400-5 and HPP600-1, the increase was around 72\%. A negative correlation was found between Distance ${ }_{\mathrm{P} 1}$ and PME activity $(R=-556 ; p<0.05)$. These results confirmed the effect of PME on texture retention after treatments, due to the tendency of demethylated pectin to form crosslinks in presence of divalent cations, such as calcium [30]. Distance ${ }_{P 1}$ is influenced not only from epidermis strength, but also from the integrity of the subdermis cells; the swollen cell walls observed after HPP treatments (Par. 3.1), probably due to the PME gelling phenomena, may have $F_{\max }$, which represents the resistance opposed by the inner tissues to the needle penetration, was reduced of around $70 \%$ after all the studied treatments in comparison to $\mathrm{R}$, despite the different phenomena were observed after blanching (cell separation) or HPP treatments (cell lysis) on the inner parenchyma.

\section{Color}

Color of zucchini, mainly related to chlorophylls and carotenoids, resulted affected by all the studied treatments, more on parenchyma than epidermis, as revealed by the higher $\Delta \mathrm{E}$ values (Table 3 ).

Blanching enhanced the green epidermis color (lower $a^{*}$, higher $C$ and $h^{\circ}$ ) in comparison to $R$, keeping almost unaltered the color of parenchyma. Same results were observed by Mazzeo et al. [31] on zucchini slices blanched in the same conditions. The color changes were attributed to modifications of the surface reflecting properties, due to air expulsion and its replacement with water and cell juices.
Fig. 3 Principal Component Analysis (PCA) results. Projection of the variables and of the cases on the factor plane $(1 \times 2)$. Abbreviations: $\mathrm{R}=$ untreated/ untreated; $\mathrm{BL}=$ blanched; 400- $1=\mathrm{HHP}$ at $400 \mathrm{MPa}$ for $1 \mathrm{~min} ; 400-5=\mathrm{HHP}$ at $400 \mathrm{MPa}$ for $5 \mathrm{~min} ; 600-1=\mathrm{HHP}$ at $600 \mathrm{MPa}$ for $1 \mathrm{~min}$; $600-5=\mathrm{HHP}$ at $600 \mathrm{MPa}$ for 5 min; $F_{\mathrm{P} 1}=$ first peak force $(\mathrm{N})$; Distance $_{\mathrm{P} 1}=$ distance of the first peak force $(\mathrm{mm})$; $F_{\text {max }}=$ absolute maximum force (N); Lp = lightness parenchyma; Le $=$ lightness epidermis; $a^{*} \mathrm{e}=$ greenness epidermis; $b^{*} \mathrm{p}=$ blueness/yellowness parenchyma; $b^{*} \mathrm{e}=$ blueness/yellowness epidermis; $\mathrm{Cp}=$ chroma parenchyma; $\mathrm{Ce}=$ chroma epidermis; $h^{\circ} \mathrm{e}=$ hue angle epidermis; $\mathrm{PC}=$ Principal Component
PC2: $28.08 \%$

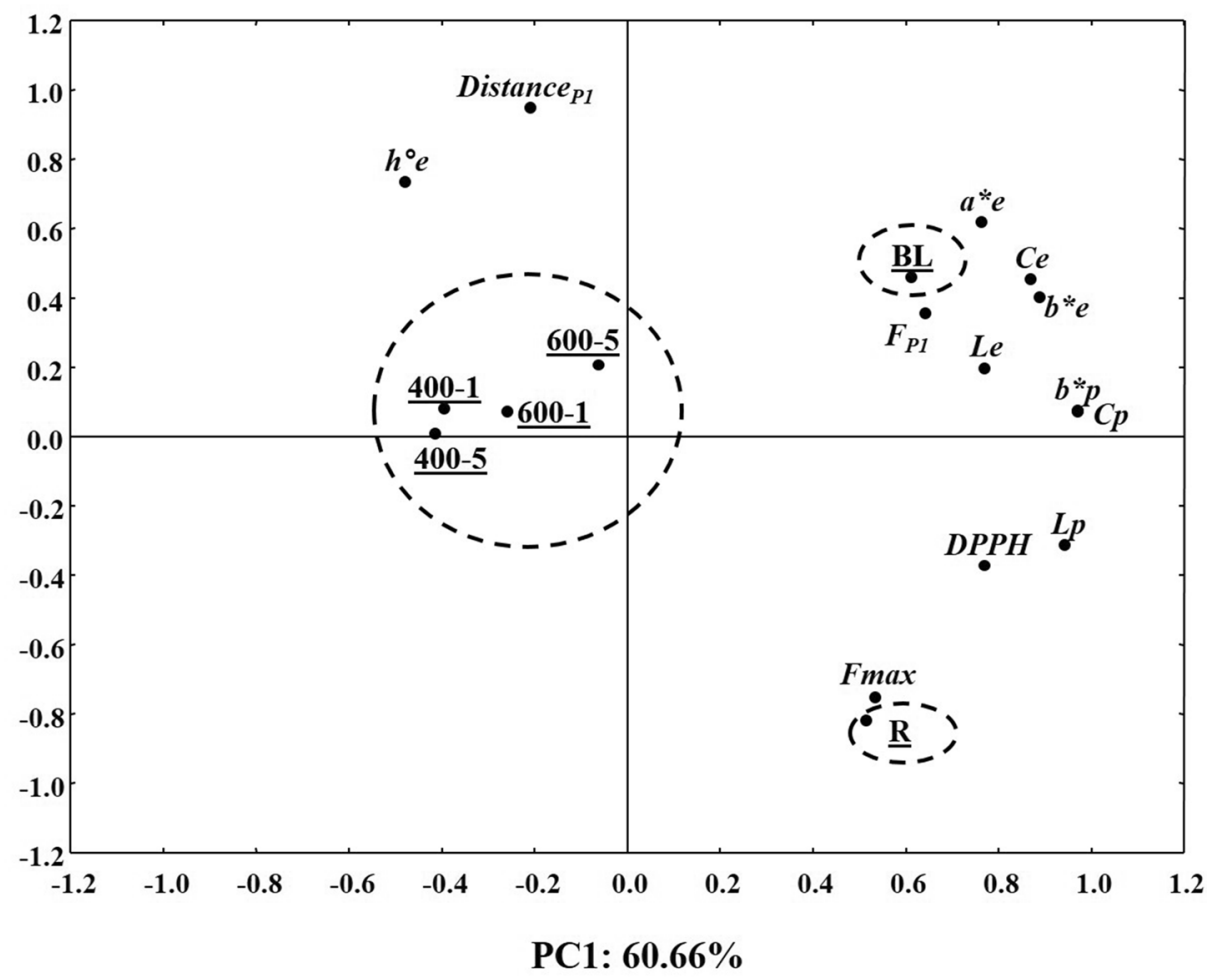


HPP treatments led to general darkening both on zucchini epidermis and parenchyma, as revealed by the lower $L, b^{*}$ and $C$ values other than the higher $h^{\circ}$, in comparison to $R$. The $a^{*}$ parameter resulted not affected by the HPP treatments. Looking at $\Delta E$ values, the parenchyma color resulted much more affected by HPP than blanching. Moreover, the 2W-ANOVA showed an influence of the pressure level on almost all the color parameters, with $600 \mathrm{MPa}$ resulting less affecting than $400 \mathrm{MPa}$. F\&V browning was already reported by other authors and related to the still high, or even enhanced, PPO activity after HPP [32]. Phenolic compounds are substrates of plant PPO, enzyme that produces brown polymers, generally leading to a decrease in visual and healthy quality.

\section{DPPH}

The radical scavenging activity of zucchini is mainly attributable to the presence of polyphenols, ascorbic acid and carotenoids, such as lutein [33]. The DPPH assay revealed how blanching did not affected the antioxidant activity of zucchini, while HPP led to a significant reduction in comparison to $R$ (Table 1). The retention of bioactive molecules after zucchini blanching was already observed by Mazzeo et al. [31].

The significant DPPH reduction after HPP may be related to still high enzymatic activities of the oxidative enzymes PPO and POD, as already reported by other authors [34]. The phenomenon is the same that leads to color browning, as already discussed in the previous paragraph. In support of this hypothesis, high correlations between $L, b^{*}$, $C$ and $h^{\circ}$ with DPPH were found, both on epidermis and parenchyma ( $L$ epidermis $R=0.554 p<0.05$, parenchyma $R=0.849 p<0.01 ; b^{*}$ epidermis $R=0.636 p<0.01$, parenchyma $R=0.645 p<0.01 ; C$ epidermis $R=0.596 ; p<0.01$; parenchyma $R=0.645 ; p<0.01 ; h^{\circ}$ parenchyma $R=-0.564$; $p<0.05$ ), suggesting oxidation both of pigments and antioxidant molecules as effect of the oxidative enzymes.

Table 1 Water content and antioxidant activity of untreated and treated zucchini

\begin{tabular}{|c|c|c|c|c|c|c|c|c|c|}
\hline & $C$ & BL & $400-1$ & $400-5$ & $600-1$ & $600-5$ & $P$ & $t$ & Pxt \\
\hline $\operatorname{PME}(\%)$ & $\begin{array}{l}100 \pm 0.0 \\
\mathrm{a}\end{array}$ & $\begin{array}{l}18.5 \pm 3.9 \\
d\end{array}$ & $\begin{array}{l}73.1 \pm 1.1 \\
\text { c C }\end{array}$ & $\begin{array}{l}86.0 \pm 7.5 \\
\text { b A }\end{array}$ & $\begin{array}{l}83.8 \pm 1.7 \\
\text { bc } \mathrm{AB}\end{array}$ & $\begin{array}{l}79.0 \pm 6.7 \\
\text { bc B }\end{array}$ & n.s & n.s & $*$ \\
\hline Water content $(\%)$ & $\begin{array}{ll} & 94.4 \pm 0.0 \\
\text { a } & \end{array}$ & $\begin{array}{l}94.9 \pm 0.2 \\
\mathrm{a}\end{array}$ & $\begin{array}{l}95.0 \pm 0.4 \\
\mathrm{aA}\end{array}$ & $\begin{array}{l}94.5 \pm 0.0 \\
\mathrm{aB}\end{array}$ & $\begin{array}{l}94.6 \pm 0.0 \\
\mathrm{aB}\end{array}$ & $\begin{array}{l}94.6 \pm 0.1 \\
\mathrm{aB}\end{array}$ & n.s & n.s & n.s \\
\hline $\mathrm{DPPH}\left(\mu \mathrm{mol} \mathrm{TE} \mathrm{g}_{\mathrm{dw}}^{-1}\right)$ & $6.84 \pm 1.24$ & $\begin{array}{l}\text { a } \\
\mathrm{a}\end{array}$ & $\begin{array}{l}3.08 \pm 0.63 \\
\text { b A }\end{array}$ & $\begin{array}{l}1.96 \pm 0.59 \\
\text { b B }\end{array}$ & $\begin{array}{l}1.71 \pm 0.38 \\
\text { b B }\end{array}$ & $\begin{array}{l}3.22 \pm 0.43 \\
\text { b A }\end{array}$ & n.s & n.s & $*$ \\
\hline
\end{tabular}

${ }^{a}$ Data are expressed as means \pm standard deviations of 3 samples. Means in rows followed by different lowercase letters are significantly different $(p \leq 0.05)$ according to the one-way ANOVA $(p \leq 0.05)$. Means in rows followed by different uppercase letters (only for high pressure treated samples) are significantly different according to $2 \mathrm{~W}$-ANOVA $(p \leq 0.05)$, performed considering pressure and time as independent variables. Abbreviations: $R$, untreated/untreated; BL, blanched; 400-1; HHP at $400 \mathrm{MPa}$ for $1 \mathrm{~min}$; 400-5, HHP at $400 \mathrm{MPa}$ for $5 \mathrm{~min}$; 600-1, HHP at $600 \mathrm{MPa}$ for $1 \mathrm{~min}$; 600-5, HHP at $600 \mathrm{MPa}$ for $5 \mathrm{~min}$; TE, Trolox equivalents

Table 2 Texture parameters for untreated and treated zucchini

\begin{tabular}{|c|c|c|c|c|c|c|c|c|c|}
\hline & \multicolumn{3}{|c|}{$F_{\mathrm{P} 1}(\mathrm{~N})$} & \multicolumn{3}{|l|}{ Distance $_{\mathrm{P} 1}(\mathrm{~mm})$} & \multicolumn{3}{|c|}{$F_{\max }(\mathrm{N})$} \\
\hline$R$ & \multicolumn{3}{|c|}{$0.47 \pm 0.05 \mathrm{a}$} & \multicolumn{3}{|l|}{$0.20 \pm 0.03 \mathrm{c}$} & \multicolumn{3}{|c|}{$4.61 \pm 0.49 \mathrm{a}$} \\
\hline $\mathrm{BL}$ & \multicolumn{3}{|c|}{$0.47 \pm 0.03 \mathrm{a}$} & \multicolumn{3}{|l|}{$0.88 \pm 0.09 a b$} & \multicolumn{3}{|c|}{$1.25 \pm 0.11 \mathrm{~b}$} \\
\hline HHP400-1 & \multicolumn{3}{|c|}{$0.40 \pm 0.03 \mathrm{~b} \mathrm{C}$} & \multicolumn{3}{|l|}{$0.90 \pm 0.19$ a A } & \multicolumn{3}{|c|}{$1.38 \pm 0.16 \mathrm{~b} \mathrm{~A}$} \\
\hline HHP400-5 & \multicolumn{3}{|c|}{$0.45 \pm 0.03 \mathrm{ab} B$} & \multicolumn{3}{|l|}{$0.72 \pm 0.11 \mathrm{~b} \mathrm{~B}$} & \multicolumn{3}{|c|}{$1.34 \pm 0.11 \mathrm{~b} \mathrm{~A}$} \\
\hline HHP600-1 & \multicolumn{3}{|c|}{$0.44 \pm 0.06 \mathrm{ab} \mathrm{B}$} & \multicolumn{3}{|l|}{$0.72 \pm 0.15 \mathrm{~b} \mathrm{~B}$} & \multicolumn{3}{|c|}{$1.41 \pm 0.22 \mathrm{~b} \mathrm{~A}$} \\
\hline \multirow[t]{3}{*}{ HHP600-5 } & \multicolumn{3}{|c|}{$0.49 \pm 0.03$ a A } & \multicolumn{3}{|l|}{$0.85 \pm 0.18 \mathrm{ab} \mathrm{A}$} & \multicolumn{3}{|c|}{$1.33 \pm 0.17 \mathrm{~b} \mathrm{~A}$} \\
\hline & $P$ & $t$ & Pxt & $P$ & $t$ & Pxt & $P$ & $t$ & Pxt \\
\hline & $*$ & $*$ & n.s & n.s & n.s & $*$ & n.s & n.s & n.s \\
\hline
\end{tabular}

Data are expressed as means \pm standard deviations of 10 samples. Means in columns followed by different lowercase letters are significantly different according to the one-way ANOVA $(p \leq 0.05)$. Means in columns followed by different uppercase letters (only for high pressure treated samples) are significantly different according to 2 W-ANOVA $(p \leq 0.05)$, performed considering pressure and time as independent variables. The $\mathrm{p}$ values were corrected for multiple comparisons use LSD method. Abbreviations: $R$, untreated; BL, blanched; HHP400-1; HHP at 400 MPa for $1 \mathrm{~min}$; HHP400-5, HHP at $400 \mathrm{MPa}$ for $5 \mathrm{~min}$; HHP600-1, HHP at $600 \mathrm{MPa}$ for $1 \mathrm{~min}$; HHP600-5, HHP at $600 \mathrm{MPa}$ for 5 min; $F_{\mathrm{P} 1}$, maximum force first peak; Distance $\mathrm{P}_{\mathrm{P}}$, distance at the maximum of the first peak; $F_{\mathrm{max}}$, absolute maximum force; $P$, pressure; $t$, Time; n.s., non-significant 


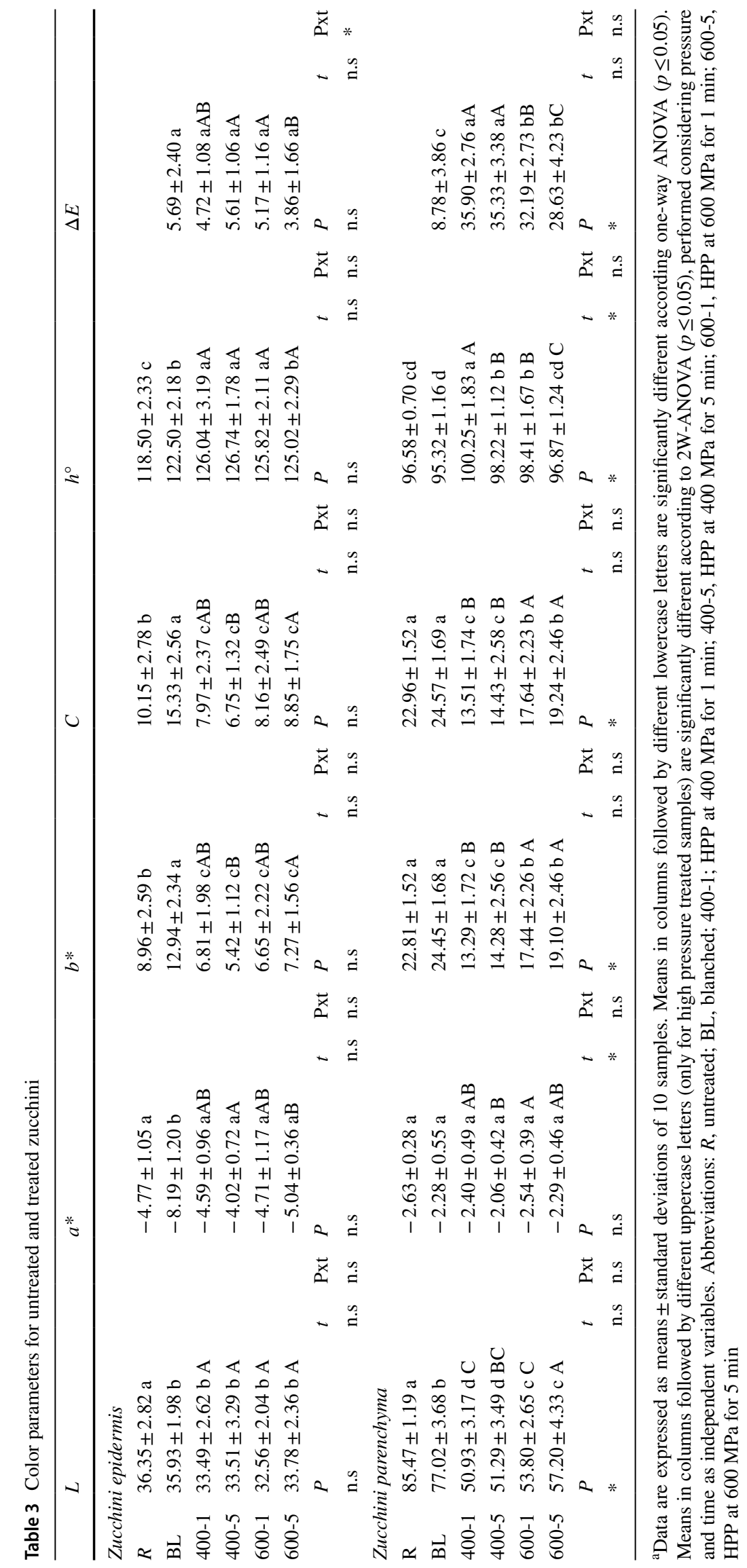


A combined effect of pressure and time was showed by the 2W-ANOVA, indicating HPP400-5 and HPP600-1 as the most affecting treatments, which led to more than $70 \%$ antioxidant activity reduction.

\section{Principal component analysis}

Figure 3 shows the results obtained from the Principal Component Analysis (PCA). Among all the studied dependent variables, the factor analysis excluded first peak force (FP1), parenchyma color parameters $a^{*}$ and $h^{\circ}$ and PME activity values, having score values lower than 0.7 . Eleven variables were selected and the first two principal components (PC) explained $88.74 \%$ of the total variance. The projection on the factorial space enabled the discrimination among the treatments: $R$, BL and HPP. $R$ samples with negative factor loadings on PC2, resulted especially described by higher $F_{\text {max }}$. BL samples, which clustered alone with positive factor loadings on PC2, resulted well described from the epidermis color parameters. On the other hand, the parenchyma color parameters, especially $\mathrm{Lp}$, and the DPPH values resulted to join R and BL samples. All the HP-treated samples clustered together, showing negative factor loadings on PC1, being however located in a middle zone on PC2. The variables that better described the HP treatments were epidermis color parameter $h^{\circ}$ and texture parameter Distance $\mathrm{P}_{\mathrm{P}}$. From the PCA results, on the base of the selected variables and processing conditions, HP-treated samples may be considered a middle way between the raw and blanched ones.

\section{Conclusion}

The effect of HP on zucchini slices is discussed here for the first time. In comparison to blanching, the use of HP at 400 and $600 \mathrm{MPa}$ for 1 and $5 \mathrm{~min}$ had a stronger impact on zucchini quality. The 2W-ANOVA, conducted among the four HP treatments, showed a combined effect of pressure and time on almost all the studied parameters. These results revealed as less advantageous the treatments 400-5 and 600-1, except for texture, which showed a better retention in those conditions, in relation to the high PME activity. The parenchyma color parameters resulted instead more affected by pressure, turning to darker color the zucchini treated with the strongest conditions. In view of these considerations, and being the tissue damages more extended on the 5 min HP-treated samples, HPP 400-1 resulted best solution for the HP treatment of zucchini. On the other hand, PCA did not find any difference among the four HP treatments, clustering them in the same group. Starting from these findings, a future investigation for the treatment of zucchini slices may be the combination of low pressures and short times using temperature as additional variable.
Author contributions MP: Conceptualization; Data curation; Investigation; Methodology; Writing—original draft;. TG: Conceptualization; Formal analysis; Investigation; Methodology; Writing — review \& editing. IGMM: Conceptualization; Data curation; Methodology; Writing-review \& editing. MR: Conceptualization; Methodology; Supervision; Validation. MR: Formal analysis; Investigation; Methodology. MM: Conceptualization; Methodology; Resources; Supervision. EC: Conceptualization; Project administration; Writing—review \& editing.

Funding Open access funding provided by Università degli Studi di Parma within the CRUI-CARE Agreement. This research did not receive any specific grant from funding agencies in the public, commercial, or not-for-profit sectors.

\section{Compliance with ethical standards}

Conflict of interest The authors declare no conflict of interest.

Compliance with ethics requirements This study does not contain any studies with human or animal subjects.

Open Access This article is licensed under a Creative Commons Attribution 4.0 International License, which permits use, sharing, adaptation, distribution and reproduction in any medium or format, as long as you give appropriate credit to the original author(s) and the source, provide a link to the Creative Commons licence, and indicate if changes were made. The images or other third party material in this article are included in the article's Creative Commons licence, unless indicated otherwise in a credit line to the material. If material is not included in the article's Creative Commons licence and your intended use is not permitted by statutory regulation or exceeds the permitted use, you will need to obtain permission directly from the copyright holder. To view a copy of this licence, visit http://creativecommons.org/licenses/by/4.0/.

\section{References}

1. Moser R, Raffaelli R, Thilmany DD (2011) Consumer preferences for fruit and vegetables with credence-based attributes: a review. Int Food Agribusiness Manag Rev 14:121-142

2. Moraes GLVD, Souki GQ, Moura LRC (2017) Behavior of consumers of fresh tomatoes: a study using factor analysis. Rural Agro-Ind Org 19:321-333

3. Aguiló-Aguayo I, Charles F, Renard CM, Page D, Carlin F (2013) Pulsed light effects on surface decontamination, physical qualities and nutritional composition of tomato fruit. Postharvest Biol Technol 86:29-36

4. Medina-Meza IG, Boioli P, Barbosa-Cánovas GV (2016) Assessment of the effects of ultrasonics and pulsed electric fields on nutritional and rheological properties of raspberry and blueberry purees. Food Bioprocess Technol 9:520-531

5. Ling B, Tang J, Kong F, Mitcham EJ, Wang S (2015) Kinetics of food quality changes during thermal processing: a review. Food Bioprocess Technol 8:343-358

6. Huang HW, Hsu CP, Wang CY (2019) Healthy expectations of high hydrostatic pressure treatment in food processing industry. $\mathrm{J}$ Food Drug Anal 28:1-13

7. Sánchez-Moreno C, Plaza L, de Ancos B, Cano PM (2003) Effect of high-pressure processing on health-promoting attributes of freshly squeezed orange juice (Citrus sinensis L.) during chilled storage. Eur Food Res Technol 216:18-22 
8. Buzrul S, Alpas H, Bozoglu F (2005) Effects of high hydrostatic pressure on shelf life of lager beer. Eur Food Res Technol 220:615-618

9. Klug TV, Martínez-Sánchez A, Gómez PA, Collado E, Aguayo E, Artés F, Artés-Hernández F (2017) Improving quality of an innovative pea puree by high hydrostatic pressure. J Sci Food Agric 97:4362-4369

10. Medina-Meza IG, Barnaba C, Villani F, Barbosa-Cánovas GV (2015) Effects of thermal and high pressure treatments in color and chemical attributes of an oil-based spinach sauce. LWT-Food Sci Technol 60:86-94

11. Paciulli M, Rinaldi M, Rodolfi M, Ganino T, Morbarigazzi M, Chiavaro E (2019) Effects of high hydrostatic pressure on physicochemical and structural properties of two pumpkin species. Food Chem 274:281-290

12. Terefe NS, Buckow R, Versteeg C (2014) Quality-related enzymes in fruit and vegetable products: effects of novel food processing technologies, part 1: high-pressure processing. Crit Rev Food Sci Nutr 54:24-63

13. Shook CM, Shellhammer TH, Schwartz SJ (2001) Polygalacturonase, pectinesterase, and lipoxygenase activities in high-pressureprocessed diced tomatoes. J Agric Food Chem 49:664-668

14. Oey I, Lille M, Van Loey A, Hendrickx M (2008) Effect of highpressure processing on colour, texture and flavour of fruit-and vegetable-based food products: a review. Trends Food Sci Technol 19:320-328

15. Krebbers B, Matser AM, Koets M, Van den Berg RW (2002) Quality and storage-stability of high-pressure preserved green beans. J Food Eng 54:27-33

16. Paciulli M, Medina Meza IG, Rinaldi M, Ganino T, Pugliese A, Rodolfi M, Barbanti D, Morbarigazzi M, Chiavaro E (2019) Improved physicochemical and structural properties of blueberries by high hydrostatic pressure processing. Foods 8:272

17. Castro SM, Saraiva JA, Lopes-da-Silva JA, Delgadillo I, Van Loey A, Smout C, Hendrickx M (2008) Effect of thermal blanching and of high-pressure treatments on sweet green and red bell pepper fruits (Capsicum annuum L.). Food Chem 107:1436-1449

18. Paciulli M, Medina-Meza IG, Chiavaro E, Barbosa-Cánovas GV (2016) Impact of thermal and high pressure processing on quality parameters of beetroot (Beta vulgaris L.). LWT-Food Sci Technol 68:98-104

19. McInerney JK, Seccafien CA, Stewart CM, Bird AR (2007) Effects of high pressure processing on antioxidant activity, and total carotenoid content and availability, in vegetables. Innov Food Sci Emerg Technol 8:543-548

20. Nguyen LT, Tay A, Balasubramaniam VM, Legan JD, Turek EJ, Gupta R (2010) Evaluating the impact of thermal and pressure treatment in preserving textural quality of selected foods. LWTFood Sci Technol 43:525-534

21. Paciulli M, Ganino T, Pellegrini N, Rinaldi M, Zaupa M, Fabbri A, Chiavaro E (2015) Impact of the industrial freezing process on selected vegetables-Part I. Structure, texture and antioxidant capacity. Food Res Int 74:329-337
22. AOAC (2002) Official methods of analysis, 16th edn. Association of Official Analytical Chemists, Arlington

23. Ruzin S (1999) Plant microtechnique and microscopy. Oxford University Press, Oxford

24. CIE (Commission Internationale de l'eclairage) (1978) Recommendations on uniform colourspaces-colour equations, psychometric colour terms. Supplement no. 2 to CIE Publ. No. 15 (E-1.3.L) 1971/9TC-1-3. Paris: CIE

25. Medina-Meza IG, Aluwi NA, Saunders SR, Ganjyal GM (2016) GC-MS profiling of triterpenoid saponins from 28 quinoa varieties (Chenopodium quinoa Willd.) grown in Washington State. J Agric Food Chem 64:8583-8591

26. Lecain S, Ng A, Parker ML, Smith AC, Waldron KW (1999) Modification of cell-wall polymers of onion waste-Part I Effect of pressure-cooking. Carbohydr Polym 38:59-67

27. Araya XIT, Hendrickx M, Verlinden BE, Van Buggenhout S, Smale NJ, Stewart C, Mawson AJ (2007) Understanding texture changes of high pressure processed fresh carrots: a microstructural and biochemical approach. J Food Eng 80:873-884

28. Sila DN, Smout C, Satara Y, Truong V, Van Loey A, Hendrickx $M$ (2007) Combined thermal and high pressure effect on carrot pectinmethylesterase stability and catalytic activity. J Food Eng 78:755-764

29. Cantwell MI, Peiser G, Mercado-Silva E (2002) Induction of chilling injury in jicama (Pachyrhizus erosus) roots: changes in texture, color and phenolics. Postharvest Biol Technol 25:311-320

30. Van Buggenhout S, Sila DN, Duvetter T, Van Loey A, Hendrickx M (2009) Pectins in processed fruits and vegetables: Part IIITexture engineering. Compr Rev Food Sci Food Saf 8:105-117

31. Mazzeo T, Paciulli M, Chiavaro E, Visconti A, Fogliano V, Ganino T, Pellegrini N (2015) Impact of the industrial freezing process on selected vegetables-Part II. Colour and bioactive compounds. Food Res Int 75:89-97

32. Tomás-Barberán FA, Espín JC (2001) Phenolic compounds and related enzymes as determinants of quality in fruits and vegetables. J Sci Food Agric 81:853-876

33. Miglio C, Chiavaro E, Visconti A, Fogliano V, Pellegrini N (2008) Effects of different cooking methods on nutritional and physicochemical characteristics of selected vegetables. J Agric Food Chem 56:139-147

34. Terefe NS, Matthies K, Simons L, Versteeg C (2009) Combined high pressure-mild temperature processing for optimal retention of physical and nutritional quality of stun treated berries (Fragariax ananassa). Innov Food Sci Emerg Technol 10:297-307

Publisher's Note Springer Nature remains neutral with regard to jurisdictional claims in published maps and institutional affiliations. 